\title{
A new species of whiptail armored catfish, genus Pseudohemiodon (Siluriformes: Loricariidae) from the Orinoco River basin, Llanos region of Colombia and Venezuela
}

\author{
Yecid Andrey Rojas-Molina ${ }^{1}$, Francisco Provenzano-Rizzi² and Hernando Ramírez-Gil ${ }^{1}$
}

A new species of whiptail armored catfish belonging to the genus Pseudohemiodon is described. The new species inhabits aquatic systems of the Orinoco River basin, mostly in the Llanos region of Colombia and Venezuela. Previously, it had identified as P. laticeps erroneously. The genus Pseudohemiodon includes seven known species inhabit Amazon and ParanáParaguay-Uruguay rivers basins. The new species is distinguished from congeners by the combination of the following characters: abdomen totally covered; area in front of gill opening without plates, ventrally; dorsal body color pattern without transversal dark bands, mostly in the caudal peduncle; head with straight sides; head and caudal peduncle narrower.

Keywords: Diversity, Freshwater fishes, South America, Systematic, Taxonomy.

Se describe una nueva especie de bagre corroncho cola de látigo perteneciente al género Pseudohemiodon. La nueva especie habita los sistemas acuáticos de la cuenca del río Orinoco, principalmente en la región de los Llanos de Colombia y Venezuela. Anteriormente, fue identificada como P. laticeps de forma errónea. El género Pseudohemiodon incluye siete especies conocidas que habitan en las cuencas de los ríos Amazonas y Paraná-Paraguay-Uruguay. La nueva especie se distingue de todos sus congéneres por la combinación de los siguientes caracteres: abdomen totalmente cubierto; sin placas delante de la abertura branquial, ventralmente; patrón dorsal de coloración del cuerpo sin bandas oscuras transversales, principalmente en el pedúnculo caudal; lados de la cabeza rectos; cabeza y pedúnculo caudal más estrechos.

Palabras-clave: Diversidad, Peces de agua dulce, Sistemática, Sur América, Taxonomía.

\section{Introduction}

The genus Pseudohemiodon was proposed by Bleeker (1862) to accommodate Hemiodon platycephalus Kner, 1853, from the Cuiabá River, Brazil (Isbrücker, 1980). The genus belongs to the subfamily Loricariinae, tribe Loricariini, Pseudohemiodon-group (Isbrücker, Nijssen, 1974; Covain et al., 2016). The Pseudohemiodon-group was originally proposed by Isbrücker, Nijssen (1974), but later was changed to the sub-tribe Planiloricariina (Isbrücker, Nijssen, 1986a), this taxonomic level was used by Rapp Py-Daniel (1997) and Provenzano (2011). Covain, FischMuller (2007) used again the name Pseudohemiodongroup, name employed currently (Covain et al., 2016). The group includes species that belong or have been included in the genera: Apistoloricaria Isbrücker, Nijssen, 1986; Crossoloricaria Isbrücker, 1979; Dentectus Martín Salazar,
Isbrücker, Nijssen, 1982; Planiloricaria Isbrücker, 1971; Pseudohemiodon Bleeker, 1862; Pyxiloricaria Isbrücker, Nijssen, 1984 and Rhadinoloricaria Isbrücker, Nijssen, 1974 (Isbrücker, 1971, 1975, 1979, 1980; Isbrücker, Nijssen, 1974, 1978, 1983, 1984, 1986a, b; Martín Salazar et al., 1982; Nijssen, Isbrücker, 1988; Chang, Castro, 1999; Rapp Py-Daniel, 1997; Provenzano, 2011; Covain et al., 2016).

Diagnosis of the genus Pseudohemiodon is not precise, and shows some ambiguity. Kner (1853) determined that Hemiodon platycephalus, type species of the genus, does not have teeth in the upper jaw, and Bleeker (1862) used this feature as diagnostic character for the genus Pseudohemiodon (Isbrücker, 1971). From its establishment until 1971, the genus was considered invalid or a subgenus of Loricaria, but that year Pseudohemiodon was revalidated and two subgenera, Pseudohemiodon and Planiloricaria were recognized (Isbrücker, 1971). In the same paper,

\footnotetext{
${ }^{1}$ Universidad de los Llanos-UNILLANOS, Km 12 Vía Puerto López, PBX, 6616800 Villavicencio, Meta, Colombia. (YARM) yecid.rojas@unillanos.edu.co, ○https://orcid.org/0000-0001-6761-5171; (HRG) hernando.ramirez@unillanos.edu.co, Dhttps://orcid. org/0000-0002-0166-3047.

${ }^{2}$ Departamento de Biología, Facultad de Ciencias, Escuela Politécnica Nacional, Quito, Ecuador, and Centro MBUCV, Instituto de Zoología y Ecología Tropical, Facultad de Ciencias, Universidad Central de Venezuela, Caracas, Venezuela. francisco.provenzano@ epn.edu.ec, (Dhttps://orcid.org/0000-0003-3296-2311 (corresponding author).
} 
Isbrücker presented a new diagnosis for the genus, but maintained the absence of teeth in upper jaw as a diagnostic feature. Isbrücker (1973) reported that Pseudohemiodon (Pseudohemiodon) included six species, but cast doubt on the absence of teeth in upper jaw as a diagnostic character, because five of the six species were found to have teeth in both jaws. Isbrücker, Nijssen (1974) considered the absence of teeth in the upper jaw of $P$. platycephalus (type species), an artifact, and indicated that all species of Pseudohemiodon have teeth in both jaws; in the same paper they elevated Planiloricaria to generic rank.

Since 1971, the number and the species included in Pseudohemiodon has changed (Isbrücker, 1971, 1973, 1975, 1979; Isbrücker, Nijssen, 1974, 1978, 1986a). Currently it includes seven species (Fricke et al., 2019). Four species inhabit the Amazon River basin: Pseudohemiodon lamina (Günther, 1868), Pseudohemiodon amazonum (Delsman, 1941), Pseudohemiodon thorectes Isbrücker, 1975 and Pseudohemiodon apithanos Isbrücker, Nijssen, 1978, and three species are cited for the Uruguay, Paraná and Paraguay, rivers basins: Pseudohemiodon platycephalus (Kner, 1853), Pseudohemiodon laticeps (Regan, 1904) and Pseudohemiodon devincenzii (Soriano Señorans, 1950) (Isbrücker, 1975, 1979, 1980; Isbrücker, Nijssen, 1978; Covain, Fisch-Muller, 2007; Covain et al., 2016). The original description of $P$. devincenzii is brief and do not provide distinctive characteristics (Soriano Señorans, 1950). The holotype, a specimen with $165 \mathrm{~mm}$ of TL and $143 \mathrm{~mm}$ of SL, has no figure or image known. Isbrücker (1979) indicate holotype of $P$. devincenzii is lost, and differences, pointed by Soriano Señorans (1950), between $P$. devincenzii and $P$. laticeps maybe related with methods and measures used. López-Rojas, Machado-Allison (1975) identify a group of specimens from the Orinoco River basin as $P$. laticeps. Isbrücker, Nijssen (1978) suggest that the specimens analyzed by López-Rojas, Machado-Allison (1975) could be close or belong to $P$. aphitanos, but the lack of morphometric data prevents a certain assignment.

Herein, a new species of the genus Pseudohemiodon is described based on specimens captured in aquatic systems of the Orinoco River basin of Colombia and Venezuela, mostly in the Llanos region.

\section{Material and Methods}

The generic placement and validity of this new species were established through the comparison with species of the Pseudohemiodon group. For comparative analyses we used original descriptions and figures of species of Pseudohemiodon (Kner, 1853; Regan, 1904; Delsman, 1941; Soriano Señorans, 1950; Isbrücker, 1975) and available specimens of species listed in comparative material examined. Also, images of type specimens from the ACSI image database (Morris et al., 2006) were used. Observations, measurements and counts were made using a Stemi dv4 stereoscopic microscope and Ubermann digital calipers. Measurements and counts were those proposed by Boeseman (1971), Isbrücker, Nijssen (1978) and Fichberg et al. (2014). Counts and nomenclature of plates follow Schaefer (1997). Measurements were taken on left side, and are expressed as percentage of standard length, head length, or in the proportions commonly used in old original descriptions for easier comparison. Museum acronyms from comparative material examined follow Sabaj (2016).

\section{Results}

\section{Pseudohemiodon unillano, new species}

urn:1sid:zoobank.org:act:76D2CFB3-7E7E-44F2-A08F31EA54B63398

\section{Figs. 1-4; Tab. 1}

Loricaria laticeps._-López-Rojas, Machado-Allison, 1975:52 [Bocono River, Venezuela].

Holotype. IAvH-P 19034, $162.0 \mathrm{~mm}$ SL, Colombia, Departamento Meta, Orinoco River basin, Guayuriba River, tributary to the upper Meta River, vía Puerto López, near Villavicencio, 0355'02.6”N 7306'11'W, 197 m asl, 2 Sep 2014, H. Ramírez-Gil and A. Ortega-Lara.

Paratypes. Colombia, Departamento Meta: IAvH-P 19089, 1, $62.4 \mathrm{~mm}$ SL, same data of holotype. IAvH-P 19035, 1, $175.3 \mathrm{~mm} \mathrm{SL}$, same data of holotype, except date of collection 01 Dec 2014. IAvH-P 19020 1, 155.7 mm SL, Guayuriba River, tributary to the upper Meta River, Orinoco River basin, 03'58'59.4'N 73²4'27.3'W, 338 m asl, 19 Nov 2014, H. Ramírez-Gil and A. Ortega-Lara. IAvH-P 19088, 1, $183.2 \mathrm{~mm}$ SL, Guayuriba River, tributary to the upper Meta River, Orinoco River basin, 0357'38.4”N 73¹6’26.3 “W, $255 \mathrm{~m}$ asl, 09 Jun 2014, H. Ramírez-Gil and A. Ortega-Lara. Departamento Casanare: MPUJ 7354, 1, $124.4 \mathrm{~mm}$ SL, caño Guanapalo, tributary of Pauto River, Meta River, Orinoco River basin, Municipio de San Luis de Palenque, vereda El Romero, 0330'38.9'N 71 56 '46.5'W, $171 \mathrm{~m}$ asl, 24 Mar 2015, V. Preciado and party. IAvH-P 3941, 1, 173.4 mm SL, Tocaria River 1994, V. Ortiz. IAvH-P 3942 , 1, 129.9 mm SL, Tocaria River, 05³3'N 72¹3'W, 02 Mar 1994, V. Ortiz. IAvH-P 3944, 1 ex., 171.4 mm SL, Tocaria River, $05^{\circ} 33^{\prime} \mathrm{N} 72^{\circ} 13^{\prime} \mathrm{W}, 02$ Mar 1994, V. Ortiz. IAvH-P 3943, 2, 167.5-195.0 mm SL, Cusiana River, 04³1'N $71^{\circ} 51^{\prime} \mathrm{W}, 11$ Nov 1994, V. Ortiz. IAvH-P 7680, 1, $144.5 \mathrm{~mm}$ SL, Cravo Sur River, 0442’N 71³6’W, 20 Nov 1995, V. Ortiz. Departamento Arauca: IAvH-P 4823, 5, 132.3-200.1 mm SL, Arauquita, Agua Limon River, 06 $55^{\prime} \mathrm{N} 70^{\circ} 58^{\prime} \mathrm{W}$, 02 Nov 1994, G. Castaño. IAvH-P 10849, 1, 110.9 mm SL, Tocaria River, 26 Jun 1983, O. Rodríguez. IAvH-P-18796, 5, 67.9-169.0 mm SL, Caño Guanapalo, San Luis del Palenque, 03³0’38.9'N 71'56’46.5”'W, 19 Aug 2015, V. Preciado. IAvH-P 19042, 5, 86.7-198.5 mm SL, Arauquita, 
Agua Limon River, 01 Nov 1994, G. Castaño. Venezuela, Estado Apure: MBUCV-V-20148, 10, 101.6-166.9 mm SL, Apure River, near San Fernando de Apure, 0752'39'N 67²5'28'W, 12 May 1989, F. Mago-Leccia and party. Estado Barinas: MCNG-51446, 6, 100.3-147.8 mm de SL, Portuguesa River, between Barinas and Guárico states, 07³3'42'N 67¹9'18'W, 03 Jan 2004, O. Castillo. MCNG5925, 5, 117.3-251.2 mm SL, Boconó River, at La Veguita, 0850'10”N 6959'30”W, 21 Jul 1980, D. Taphorn. Estado Portuguesa: MBUCV-V-12984, 15, 164.6-226.9 mm SL, Boconó River, Puerto Sunsún, 0845'11'N 6950'22’'W, 25 Sep 1973, F. Mago, O. Silva, A. Machado and L. Aguana.

Non-type specimens. Venezuela, Estado Apure: MCNG 13866, 1, $122.8 \mathrm{~mm}$ SL, Apure River, $10 \mathrm{~km}$ downstream San Fernando de Apure, 0751'50'N 67²3'30'W, 15 May 1985, D. Taphorn. Estado Barinas: MBUCV-V-12923, 1, $63.0 \mathrm{~mm}$ SL, Masparro River, at Libertad bridge, $08^{\circ} 20^{\prime} 33^{\prime \prime} \mathrm{N}$ 69³9’20”W, 31 Jul 1981, F. Provenzano, O. Castillo and L. Aguana. MCNG 11974, 4, 29.5-45.4 mm SL, Caparo River, 10 Km from El Cantón, 07²9’30”N 71¹3’00”W, 21 Dec
1983, D. Taphorn. Estado Bolívar: MBUCV-V-16885, 2, 78.6-80.5 mm SL, Orinoco River, at Caura River confluence, beaches, canals and lagoon nearby Puerto Las Majadas, approx. $07^{\circ} 38.6^{\prime} \mathrm{N}$ 6450'W, 23 Nov 1985, B. Chernoff, J.G. Lundberg, and L. Aguana. MBUCV-V-16900, 1, 87.2 $\mathrm{mm}$ SL, Cuchivero River, at ferry boat crossing point, 07²9'N 653' $\mathrm{W}, 17$ Nov 1985, B. Chernoff and party. Estado Cojedes: MBUCV-V-12781, 2, 50.5-51.4 mm SL, Salinas River, Pao viejo River channel, NE from El Baúl, 0915’ N 68¹1'W, 25 Feb 1950, A. Fernández-Yépez. Estado Guárico: MBUCV-V-16859, 6, 59.2-106.9 mm SL, Guariquito River, at confluence with Orinoco River, 07³9'28'N 66¹9'52”W, 25 Nov 1985, B. Chernoff, B. Saúl, R. Royero and L. Aguana. Estado Monagas: MCNG 29133, 1, $76.3 \mathrm{~mm}$ SL, Guanipa River, at the bridge, approx. 5 km S del Aguasay, 09²2'06”N 6346'47'W, 1 Jul 1994, D. Taphorn. Estado Portuguesa: MCNG 5539, 4, 142.2222.0 mm SL, Boconó River, La Veguita, 0850’10”N 6959'30'W, 11 Jun 1982, D. Taphorn. MCNG 19394, 1, $277.1 \mathrm{~mm}$ SL, Portuguesa River, at the bridge on principal highway, 0905'00’N 6941'30”W, 31 Mar 1987, ASF87-2.

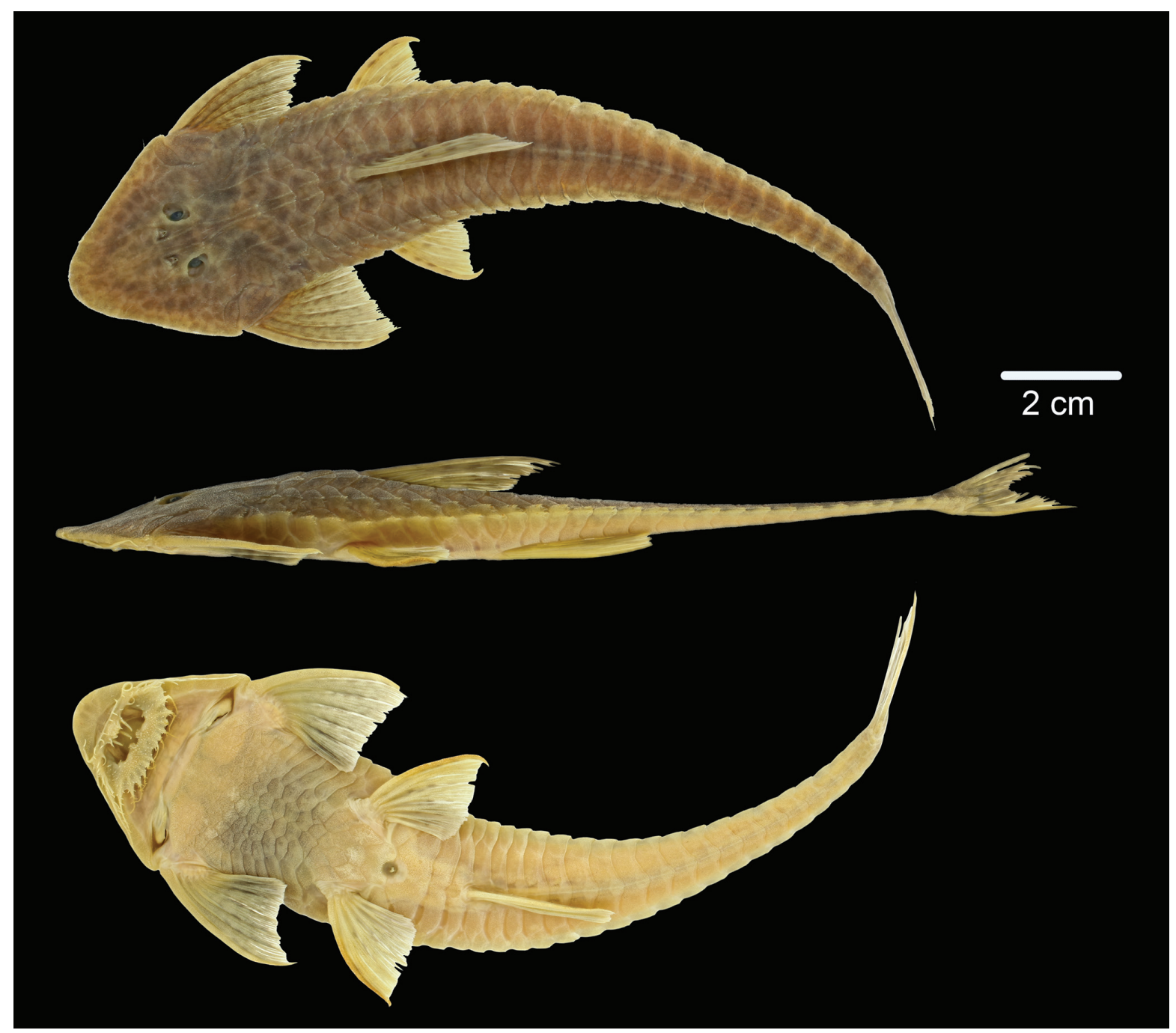

Fig. 1. Pseudohemiodon unillano, new species, holotype, IAvH-P 19034, 162.0 mm SL. Photograph by J. Lopez-Castaño. 
Diagnosis. Pseudohemiodon unillano is distinguished from $P$. platycephalus, $P$. amazonum and $P$. thorectes by its abdomen totally covered with small to medium-sized, irregularly shaped plates ( $v s$. abdomen partially covered, or if completely covered, plates on central row are wide and rectangular). Further distinguished from $P$. lamina by the absence of bony plates anterior to gill openings, in ventral view of head ( $v s$. presence of one or more plates in front of the gill openings). From P. apithanos by its body color pattern, dorsally, uniform light brown with dark fine lines or with dark (black) spots small and irregular; caudal peduncle without dark transverse bands ( $v s$. anterior region of body very dark brown, or light brown with dark-colored fine lines, and caudal peduncle with three dark transverse bands, the first, broad, located at the end of dorsal-fin, the other two thinner and posterior; transversal bands could be absent in larger specimens). From $P$. laticeps by its head narrower, cleithral width 1.0 times or less in HL, with straight sides (vs. head wider, cleithral width 1.1 or more times in HL, with sides slightly concave near tip of snout).

Description. Morphometric data presented in Tab. 1. Head and body very depressed, caudal peduncle long, narrow and very depressed, without adipose-fin. Body deepest at dorsal-fin origin or slightly ahead, and widest at cleithrum, becoming narrower posteriorly, gradually, to caudal-fin origin. Dorsal profile of body from tip of snout through anterior border of eye, straight and sloping more or less $45^{\circ}$, from this point to dorsal-fin origin, straight and gently inclined or gently convex, then descending straight to caudal-fin origin. Ventral profile of body flat and straight. Head triangular, in dorsal view, sides straight. Snout slightly projected, with rounded tip. Pectoral-fin origin insertions at vertical through posterior margin of orbit. Dorsal-fin origin opposite pelvic-fin origin. Anal-fin origin at lateral plate number 10 (Fig. 1).

Eyes located dorsally, orbit with evident anteroventral and posterior notch. From nostrils, parallel slight keels run posteriorly, passing between eyes to anterior tip of supraoccipital. Keels convergent posteriorly, over supraoccipital, becoming narrower and parallels, to posterior tip on supraoccipital. Predorsal region with three single plates, first and second plate with parallel low keels, and third plate with single one, on midline (Fig. 1).

Body sides with 31-32 plates at median lateral series, 1315 coalescent plates (double keel) and 17-19 posterior plates (one keel). Six to eight thoracic plates (between posterior end of pectoral-fin base and origin of pelvic-fin base). Postdorsal plates 20-22 and post-anal plates 17-20. Four plates along dorsal-fin base and two or three plates along anal-fin base.

Abdomen completely covered in specimens greater than $70.0 \mathrm{~mm} \mathrm{SL}$, with small to medium-sized, irregularly, polygonal-shaped plates, smaller over pectoral girdle. Ventral surface of head naked, except by plates surrounding its border and on snout; no plates anterior to gill openings.
Tab. 1. Morphometric data of Pseudohemiodon unillano, new species, in $\%$ of standard length, $n=30$.

\begin{tabular}{|c|c|c|c|c|c|}
\hline Characters & Holotype & Average & STD & Min & Max \\
\hline Standard length (SL) & 162.0 & & & 62.4 & 200.5 \\
\hline Head length & 24.8 & 24.5 & 1.0 & 22.9 & 26.7 \\
\hline Predorsal length & 34.9 & 34.3 & 1.0 & 32.1 & 36.8 \\
\hline Postdorsal length & 55.8 & 56.8 & 1.2 & 53.7 & 59.2 \\
\hline Preanal length & 49.1 & 48.0 & 1.1 & 46.0 & 51.0 \\
\hline Cleithral width & 23.5 & 23.0 & 1.2 & 20.8 & 24.9 \\
\hline Postanal length & 46.2 & 47.5 & 1.4 & 44.0 & 49.8 \\
\hline Pre-pectoral length & 20.0 & 19.4 & 0.9 & 17.9 & 22.0 \\
\hline Abdominal length & 15.3 & 14.1 & 0.9 & 12.1 & 15.6 \\
\hline Thoracic length & 19.7 & 19.2 & 0.9 & 17.1 & 20.8 \\
\hline Dorsal-fin length & 21.8 & 20.1 & 1.3 & 17.6 & 23.1 \\
\hline Pectoral-fin length & 19.3 & 18.5 & 0.8 & 16.5 & 19.8 \\
\hline Last pectoral-ray length & 7.7 & 8.0 & 0.6 & 6.7 & 9.4 \\
\hline Pelvic-fin length & 14.4 & 14.0 & 1.3 & 11.7 & 16.5 \\
\hline Anal-fin length & 17.1 & 15.7 & 1.0 & 14.0 & 17.6 \\
\hline Body depth at dorsal-fin origin & 8.8 & 8.6 & 0.9 & 7.2 & 10.2 \\
\hline Minimum caudal peduncle depth & 1.8 & 1.6 & 0.2 & 1.2 & 2.0 \\
\hline Body width at dorsal-fin origin & 18.9 & 17.9 & 1.8 & 12.1 & 21.2 \\
\hline Body width at anal-fin origin & 15.2 & 14.7 & 1.1 & 11.9 & 17.1 \\
\hline Body width at caudal-fin origin & 3.1 & 2.7 & 0.4 & 1.5 & 3.4 \\
\hline Head width & 24.6 & 24.1 & 0.8 & 22.5 & 25.9 \\
\hline Head depth & 7.8 & 7.5 & 0.6 & 6.5 & 9.0 \\
\hline Interorbital distance & 4.3 & 4.4 & 0.6 & 3.8 & 6.7 \\
\hline Orbital diameter & 1.7 & 1.9 & 0.3 & 1.4 & 2.4 \\
\hline Orbital-predorsal length & 19.1 & 18.1 & 0.7 & 16.7 & 19.8 \\
\hline Snout length & 14.5 & 13.8 & 0.6 & 11.6 & 14.8 \\
\hline Snout nostril length & 11.9 & 11.5 & 0.5 & 10.5 & 12.7 \\
\hline Nostril length & 1.9 & 1.5 & 0.3 & 1.0 & 2.0 \\
\hline Inter-nostril distance & 2.0 & 2.1 & 0.2 & 1.8 & 2.3 \\
\hline Dentary length & 0.9 & 0.9 & 0.1 & 0.6 & 1.2 \\
\hline Lower lip width & 14.2 & 12.4 & 1.5 & 8.5 & 15.3 \\
\hline Lower lip length & 2.0 & 2.1 & 0.4 & 1.4 & 2.8 \\
\hline Oral cavity width & 6.3 & 6.0 & 0.5 & 4.9 & 7.1 \\
\hline Premaxillary ramus & 0.8 & 0.8 & 0.1 & 0.6 & 1.2 \\
\hline
\end{tabular}

Branchiostegal membrane smooth and uniform, without wrinkled flap on anterior margin or any protuberance or fold (Fig. 1). Anus projected as very small tube, urogenital papilla not visible, apparently attached to posterior surface of anal tube. Anus delimited by narrow naked area, surrounded by plates (Fig. 1).

Mouth ventral with expanded, thin and laminar lips. Upper lip very narrow, its border with conical small barbels or cirri, elongated and unbranched, long and short cirri interspersed. Upper lip surface has sparse small papillae. Border of upper lip continuous with maxillary barbel, extending to gill opening, sometimes reaching pectoral-fin base. Maxillary barbel with small, conical, unbranched cirri. Lower lip wide, its border with elongated and branched conical small barbels, central shorter. Lower lip surface covered with short, fleshy, soft and thick papillae, sometimes little elongated (Figs. 1, 2). 
On distal side of each premaxilla, two or three elongate, soft, fleshy, cylindrical, unbranched small barbels. At center of oral cavity and posterior to premaxillaries, single small barbel long, soft, fleshy, cylindrical and unbranched (Figs. 2,3 ). Teeth present in both jaws, very minute but evident, all with same size; bicuspids asymmetrical, but sometimes symmetric after wear; inner cusp more developed, spoonshaped, outer cusp very small, sometimes not visible, and pointed; apex yellow or golden. Premaxillary teeth 5-9, dentary teeth 5-10 (Fig. 3).

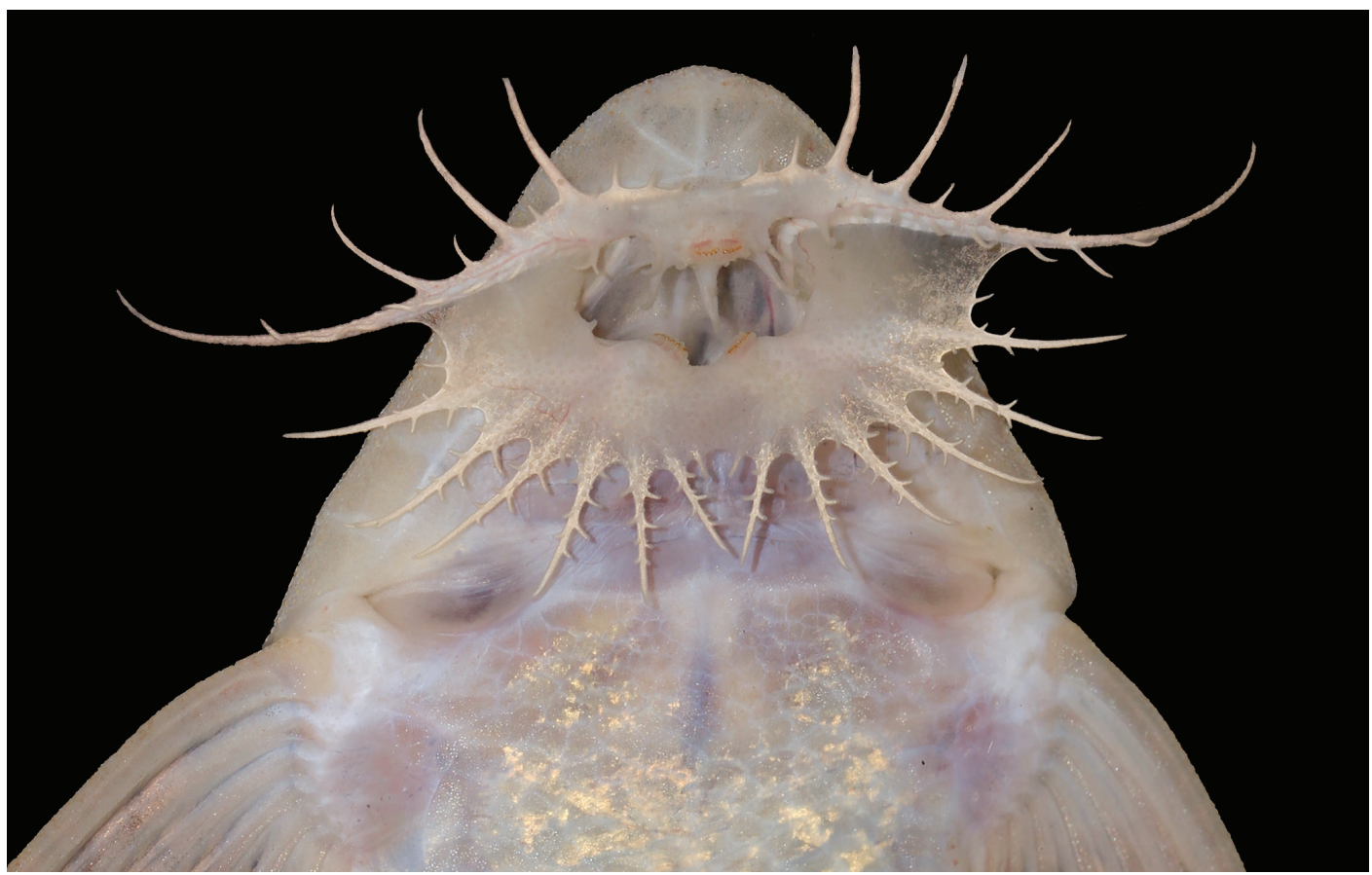

Fig. 2. Pseudohemiodon unillano, paratype, IAvH-P 19088, $183.2 \mathrm{~mm}$ SL. Detail of mouth in live specimen. Photograph by A. Ortega-Lara.

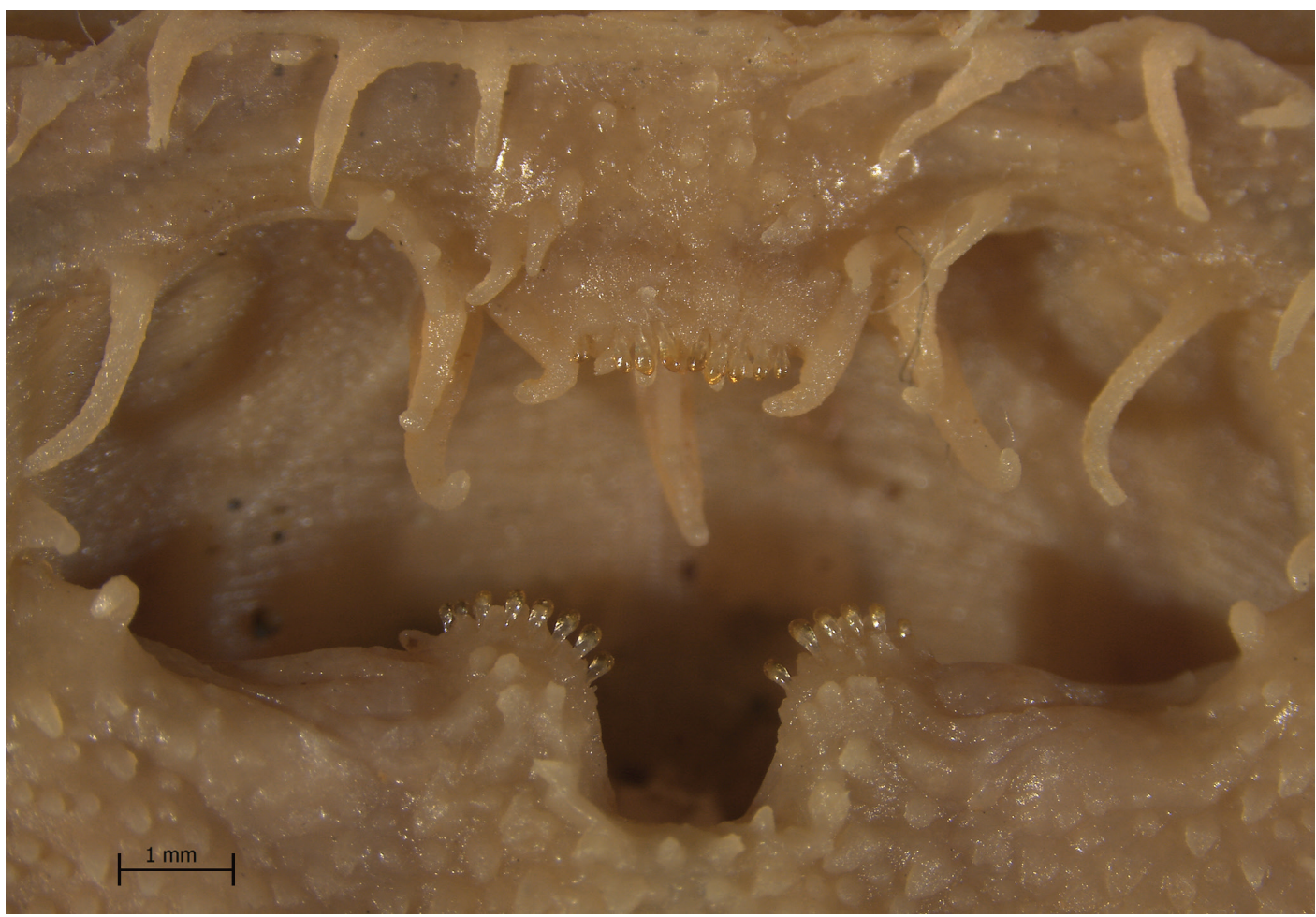

Fig. 3. Pseudohemiodon unillano, paratype, IAvH-P 19088, $183.2 \mathrm{~mm}$ SL. Detail of buccal ornamentation and teeth. Photograph by L. M. Mesa. 
Dorsal-fin rays $i, 7$; pectoral-fin rays i,6; pelvic-fin rays $i, 5$; anal-fin rays $i, 5$; and caudal-fin rays $i, 10$,i. Tip of pelvic fins surpassing origin of anal fin. Caudal fin slightly bifurcated, with unbranched rays longer than branched. Upper unbranched ray of caudal-fin extend as very long filament (Fig. 4). In examined specimens, first unbranched ray of dorsal, pectoral, pelvic and anal fins not elongated as filament.

Largest specimen examined $277.1 \mathrm{~mm} \mathrm{SL}$ (MCNG 19394).

Color in alcohol. Specimens preserved in $70 \%$ alcohol with dorsal surface of head and body, yellowish or light brown, uniform, sometimes with random pattern of irregular square or rectangular, dark or brown blotches, mostly on head and trunk (Fig. 1). Ventral surface of head and body, whitish, yellowish, or pale brown, uniform (Fig. 1). Dorsal, pectoral, pelvic and caudalfins with rectangular or square dark or black blotches on rays; interradial membranes hyaline. Dorsal, pectoral and pelvic-fins spines with five, seven and four black blotches, respectively. Anal-fin uniform, may be whitish or yellowish (Fig. 1). Caudal-fin with three to five rectangular black blotches on rays, sometimes blotches faded or as two or three transverse dark bands when caudal-fin not completely open (Fig. 1).

Coloration in life. Live specimens with dorsal and lateral surfaces of body may be yellowish or grayish with vermicular pattern of dark, very narrow lines, and iridescent tonalities. Ventral surface of body, may be whitish or yellowish, uniform. Edge of snout light brown. Dorsal, pectoral and pelvic fins with dark or black blotches on rays; interradial membranes hyaline. Dorsalfin with rectangular black blotches similar in size and shape in all rays. Pectoral-fin rays with rectangular black blotches at bases, and square-shaped on rest of fin. Pelvicfin rays base, and rays five and six whitish, uniform; rays one to four with rectangular black blotches on its distal two thirds. Anal-fin may be whitish or yellowish, uniform, without blotches. Caudal-fin base, whitish, rays with six to eight black, rectangular blotches; elongated, dorsal unbranched ray, with black blotches until its end. Interradial membrane of all fins hyaline (Fig. 4).

Geographical distribution. Records indicate that the species lives along Orinoco River basin and has a wide geographical distribution; mostly it is found in flatlands region (Llanos), from the foothills of the Eastern Andes in Colombia and the Mérida Cordillera until near the Orinoco River delta, in Venezuela (Fig. 5).

Etymology. The species name "unillano", is taken from the Latin prefix "uni" which means: one, unique, and from the Spanish word "llano" which means: a plain terrain. Alluding the savannas or plains share by Colombia and Venezuela, crossed by tributaries and the Orinoco River itself. A noun in apposition.

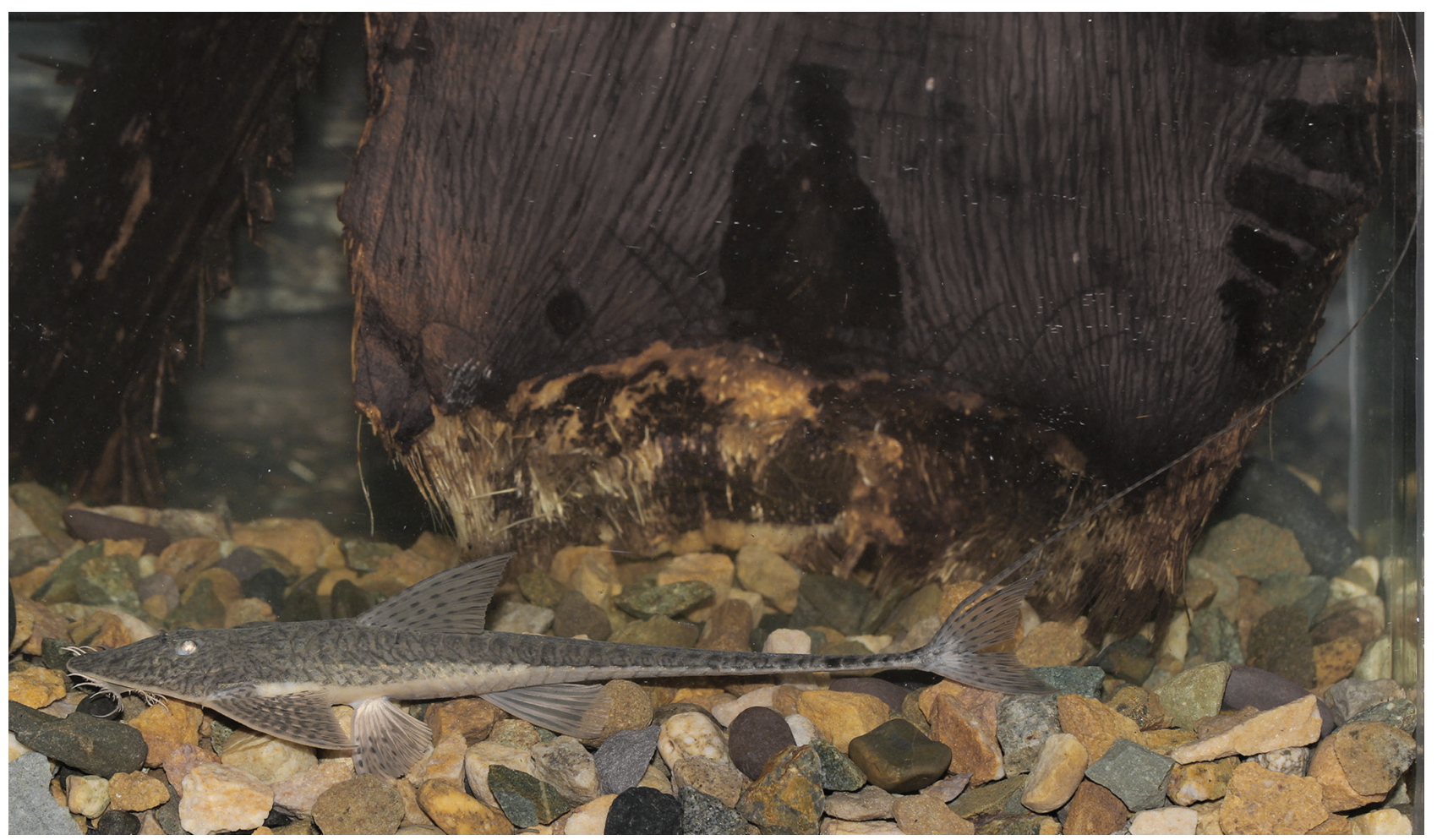

Fig. 4. Pseudohemiodon unillano, paratype, IAvH-P 19088, $183.2 \mathrm{~mm}$ SL. Coloration in live specimen. Photograph by A. Ortega-Lara. 


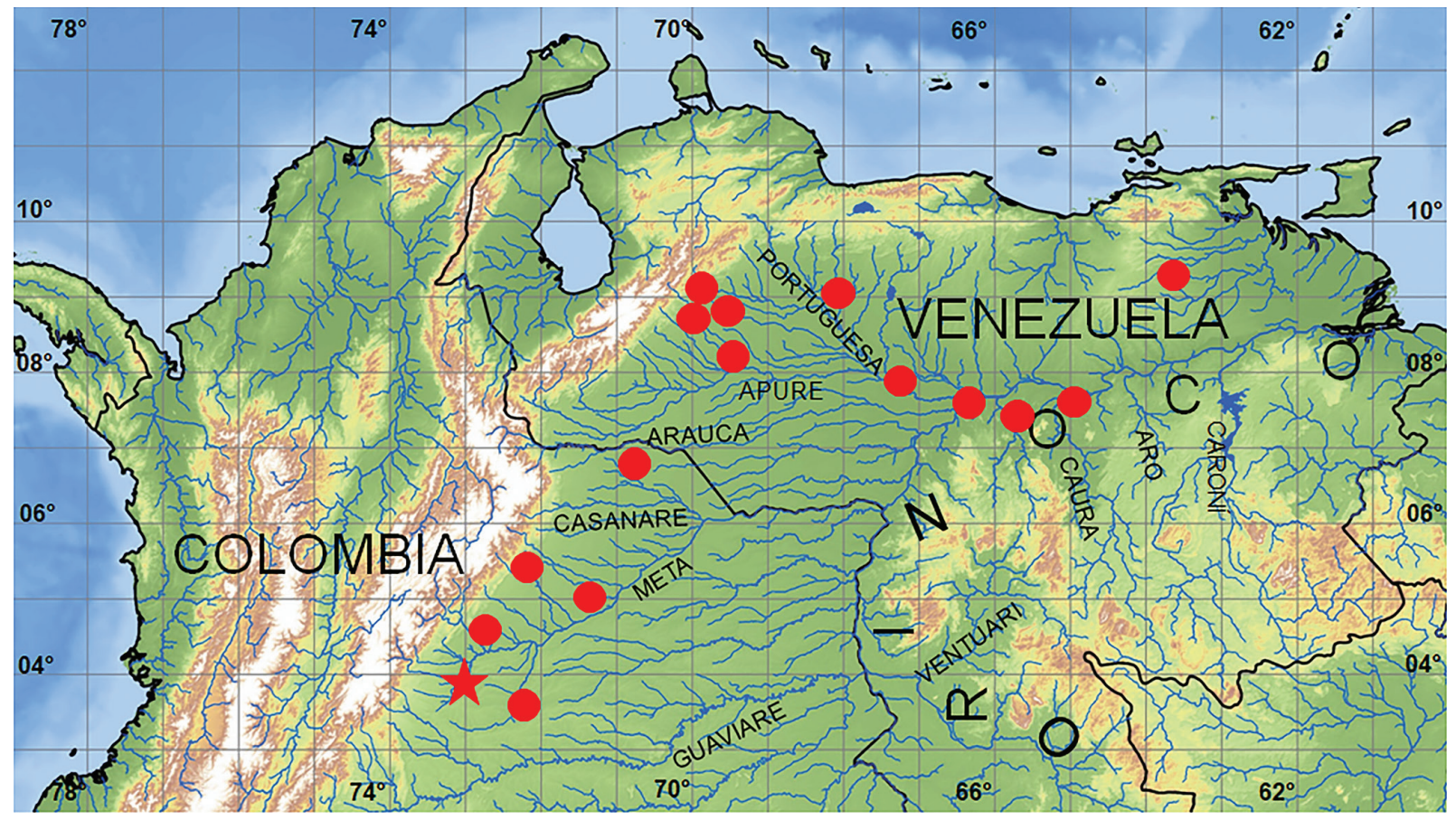

Fig. 5. Map of northern South America (Colombia and Venezuela) showing capture localities of Pseudohemiodon unillano, red star is type locality, some symbols may represents more than one lot.

Ecological notes. Pseudohemiodon unillano inhabits rivers and flooded areas at altitudes ranging from 135 to $334 \mathrm{~m}$ asl, in areas with gentle slope (between 0 and 3 percent) and sandy or clay substrate. In waters from high turbidity $(316 \mathrm{mg} / 1$ total solids) to slightly clear, with $\mathrm{pH}$ between 6.7 and 8.6, conductivity between 117.5 and 387 $\mu \mathrm{S} / \mathrm{cm}$, oxygen concentration between 0.9 and $8.76 \mathrm{mg} / \mathrm{l}$, with percentage of saturation between 20 to $83 \%$, and temperature between 25 and $30.7^{\circ} \mathrm{C}$. In a sample carried out at Guayuriba River, Colombia, Pseudohemiodon unillano was captured with anostomids (Laemolyta taeniata, Leporinus striatus), apteronotids (Apteronotus galvisi, A. albifrons, Sternarchorhynchus roseni), characids (Creagrutus taphorni, Gephyrocharax valencia, Hemibrycon metae), crenuchids (Characidium boavistae), heptapterids (Cetopsorhamdia orinoco, C. shermany, Imparfinis pseudonemacheir, Phenacorhamdia anisura, P. taphorni), loricariids (Farlowella mariaelenae, Lamontichthys llanero, Chaetostoma formosae, Pterygoplichthys gibbiceps, Spatuloricaria terracanticum).

Conservation status. According registers, P. unillano is common and abundant species, with wide geographical distribution. No specific threats are known, thus tentatively is categorized as Least Concern (LC) according to the International Union for Conservation of Nature (IUCN) categories and criteria (IUCN Standards and Petitions Subcommittee, 2017). On the other hand, type locality is intensely affected by extraction of sand, gravel and boulders, and deforestation of the riparian forest (Ajiaco-Martínez et al., 2015), with negative impacts on local populations of $P$. unillano.

\section{Discussion}

Our results indicate that Pseudohemiodon unillano $\mathrm{n}$. sp. unambiguously belongs to the subfamily Loricariinae, tribe Loricariini, and Pseudohemiodon-group. The external morphological characters that supports this conclusion are: head and body very depressed, especially the caudal peduncle; dorsal-fin opposite the pelvic-fins; adipose fin absent; ten branched caudal-fin rays; orbital notch present; maxillary barbel conspicuous; teeth few and small, but visible in both jaws. Among genera included in the Pseudohemiodon-group, the new species certainly belongs to Pseudohemiodon, share more external characters and is more similar to species included in it. Shared characters include: head triangular in shape, with rounded anterior border; snout not projected; teeth visible in both jaws; maxillary barbel reaching or surpassing gill opening, but never extending to pectoral-fin base. The external morphology in Rhadinoloricaria species and Dentectus barbarmatus Martín Salazar, Isbrücker, Nijssen 1982 are quite different; in dorsal view, head never is triangular in shape, some species of Rhadinoloricaria have the snout projected, the abdomen is partially covered, and the maxillary barbel surpasses pectoral-fin base. Also, species of both genera have buccal morphology very different to that observed in Pseudohemiodon species (see Günther, 1869: figs. 5-6; Martín Salazar et al., 1982: figs: 2-3; Isbrücker, Nijssen, 1983: figs. 1-2; 1986b: figs. 1-3; Nijssen, Isbrücker, 1988: figs 2-10; Chang, Castro, 1999: figs 1-2). Species of Crossoloricaria, Planiloricaria cryptodon (Isbrücker, 1971) and Pyxiloricaria menezesi Isbrücker, Nijssen 1984 have similar gross morphology, but in Planiloricaria cryptodon 
the maxillary barbel reaches beyond the pectoral-fin base, the lower lip surface is narrower, with longer barbels on its border, and the upper jaw is edentulous (Isbrücker, Nijssen, 1986a: fig. 3). Pyxiloricaria menezesi has the anterior margin of the branchiostegal membrane with a large, fleshy, wrinkled flap, and a peculiar head shape (Isbrücker, Nijssen, 1984: fig. 4). Species of Crossoloricaria have the abdomen partially covered with plates, with a single narrow series along the midline, leaving naked areas at the sides (Sciuiltz, 1944: Pl: 12, fig. C; Isbrücker, 1979: figs. 18-19).

Additionally, as previously indicated by Provenzano (2011), the new species and other examined Pseudohemiodon species exhibit a particular pattern of the buccal morphology and ornamentation as follows: maxillary barbel can extend to anterior border of pectoral-fin base, but rarely surpasses it. Lip surfaces, especially the lower lip, are covered with fleshy, soft and thick papillae, sometimes little elongated. Lip borders have soft, fleshy, elongated, cylindrical, and branched small barbels or cirri, those at the center are smaller, mainly on border of lower lip. Inside the mouth, at distal side of each premaxilla, there are two or three, soft, fleshy, cylindrical, unbranched small barbels, and behind and between premaxillary, just at the center of the mouth roof, one small barbel, soft, fleshy, cylindrical, unbranched and longer (Figs. 2, 3, 6). The species of Crossoloricaria have a very similar buccal ornamentation to species of Pseudohemiodon, but there are two soft, fleshy, unbranched elongated small barbels, behind and between premaxillary, just at the center of the roof of the mouth (Fig. 6). Described buccal morphology or ornamentation and some external morphological characters allow a more certain identification of species belonging to Pseudohemiodon.

Original figures and descriptions, available images of type specimens (Günther, 1868: fig. 7; Regan, 1904: pl. XX, fig.1; Isbrücker, Nijssen, 1978: fig. 6, Morris et al., 2006), plus available specimens of $P$. lamina and $P$. apithanos, indicate that $P$. unillano seems to be closer to $P$. lamina, $P$. laticeps and $P$. apithanos. These species have similar or almost identical abdominal cover, i.e. abdomen completely covered by irregular, medium to small sized plates. In P. platycephalus and $P$. thorectes, the abdomen has a middle longitudinal series of wide, rectangular plates (Kner, 1853; Isbrücker, 1975: fig. 2). The condition in P. amazonum is doubtful, the image of holotype at ACSI database (Morris et al., 2006) shows the abdomen partially covered, but Isbrücker (1975:90) indicates the abdomen completely covered by small bony plates. The color pattern of $P$. unillano is similar to $P$. lamina and $P$. laticeps, but $P$. lamina has plates in front of gill openings and the sides of the snout are somewhat concave. The original description of $P$ devincenzii is very brief and does not provide distinctive characters. Additionally, no figures or images of the holotype are known. Therefore, making a comparison with $P$. devincenzii is somewhat prohibitive. Soriano Señoras (1950) indicate that the shape of lips and the arrangement and size of abdominal plates separate $P$. devincenzii from $P$. laticeps. According to our analysis, these differences are not conclusive. Without conclusive and confident data, taxonomic status of $P$. devincenzii still remains uncertain. It is unlikely that a species native to the Uruguay River basin could be the same species that inhabits the Orinoco River basin. Based in geographical distribution we conclude that $P$. unillano and $P$. devincenzii are different.

The geographical distribution of $P$. laticeps, $P$. lamina, $P$. apithanos and $P$. unillano n. sp. includes Parana-Paraguay, Amazon and Orinoco rivers basins, therefore this provides an excellent opportunity to propose a biogeographical hypothesis of the sequence of events that resulted in the separation of the three basins using the typology of the phylogenetic hypothesis of these four species.

Finally, Isbrücker, Nijssen (1978) suggested that $P$. laticeps may be present in the Pastaza River basin, Ecuador. Preliminary observations of an ongoing project on the species of Pseudohemiodon from Ecuador, indicate that $P$. laticeps is not present in Ecuadorian tributaries of the Amazon River basin.

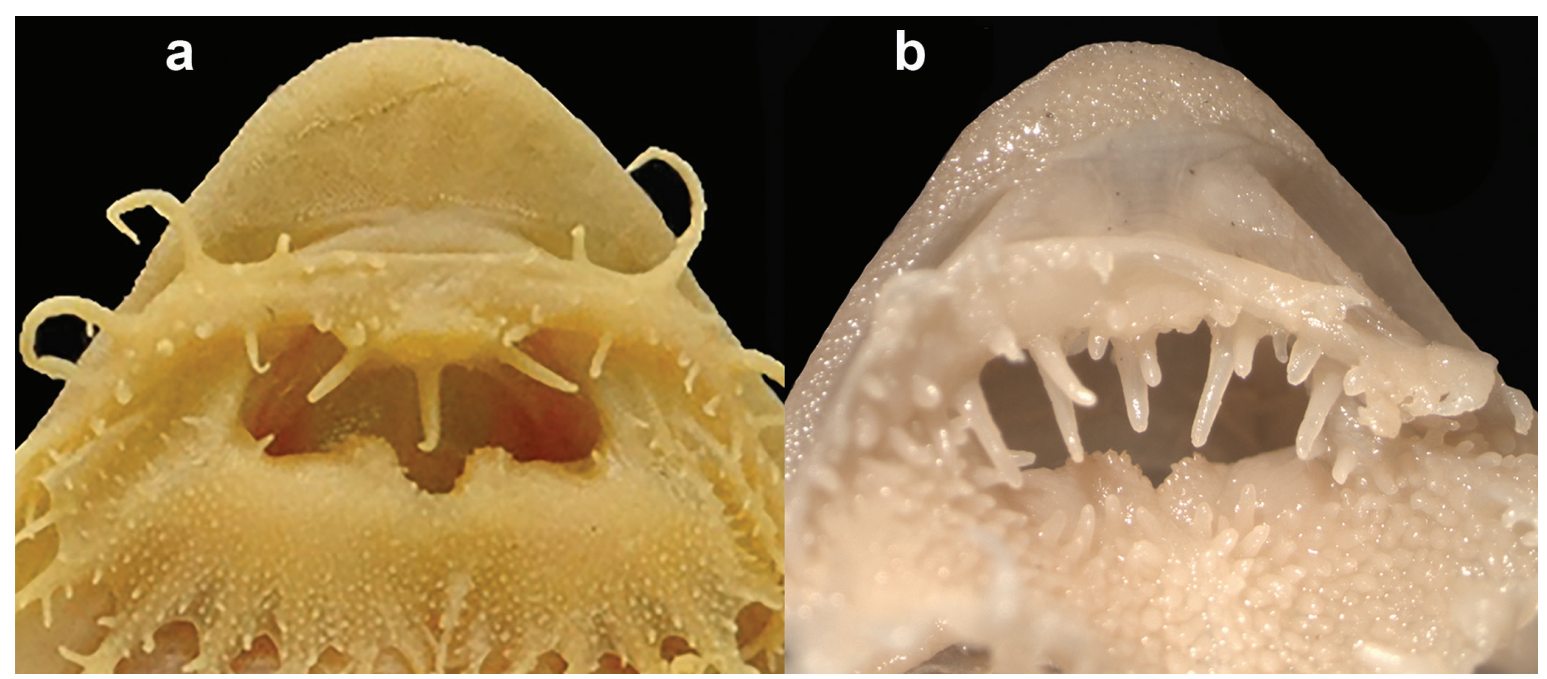

Fig. 6. Detail of buccal ornamentation. a. Pseudohemiodon unillano, paratype, MBUCV-V-20148, $166.9 \mathrm{~mm}$ SL; b. Crossoloricaria venezuelae, MBUCV-V-2175, $57.8 \mathrm{~mm}$ SL. 
Comparative material examined. Apistoloricaria condei: Ecuador: MEPN 3041, paratype, 140.0 mm SL; Provincia Orellana, río Aguarico, afluente del río Napo. Crossoloricaria bahuaja: Perú: MUSM 9916, holotype, 115.9 mm SL; Departamento Madre de Dios, Rio Tambopata. Crossoloricaria venezuelae: Venezuela: MBUCV-V-16357, 24, 120.0-172.0 mm SL, Estado Zulia, río Apón, cuenca Lago de Maracaibo. Dentectus barbarmatus: Venezuela: MBUCV-V-7406. 3, 143.0-145.0 mm SL; Estado Portuguesa, río Boconó, afluente río Portuguesa. Planiloricaria cryptodon: Peru: MBUCV-V-33026 (ex. ANSP 182304), 3, 87.0-174.0 mm SL; Loreto, río Amazonas. Pseudohemiodon lamina: Ecuador: MEPN 16771, 1, $169.4 \mathrm{~mm}$ SL; Provincia Orellana, Río Tiputini, afluente del río Napo. Pseudohemiodon apithanos: Ecuador: MEPN 18375, 1, 174.0 mm SL; Provincia Sucumbíos, Río Aguarico, afluente del río Napo. Pyxiloricaria menezezi: Brazil: MZUSP 26800, $90.1 \mathrm{~mm}$ SL, holotype of Pyxiloricaria menezesi Isbrücker, Nijssen 1984; Estado Mato Grosso do Sul, marginal lagoons at Transpantaneira highway. Rhadinoloricaria laani: Venezuela: MBUCV-V-19332, 17, 92.8119.4 mm SL; Estado Apure, río Apure, afluente del río Orinoco. Rhadinoloricaria sp.: Ecuador: MEPN 18664, 1, 114.4 mm SL; Provincia Sucumbíos, Río Jivino Negro, afluente del río Napo.

\section{Acknowledgments}

We wish to thank the following institutions and persons for their support and assistance provided for examination of specimens under their care. Universidad de los Llanos ECOPETROL (Project $\mathrm{N}^{\circ}$ 5211592). C. DoNascimiento, J. Albornoz and A. Méndez, IAvH, Fish Collection, Villa de Leyva, Colombia. S. Prada and A. Urbano, MPUJ, Fish Collection, Bogota, Colombia. J. López-Castaño, Colombia. A. Ortega-Lara, Cali, Colombia. R. Barriga-Salazar, MEPN, Fish Collection, Quito, Ecuador. H. Ortega, L. Chumbe Nolasco, MUSM, Lima, Peru. O. E. Castillo, MCNG, Fish Colletion, UNELLEZ, Guanare, Venezuela. A. Marcano, MBUCV, Fish Collection, Caracas, Venezuela. Thanks to D. Taphorn and two anonymous reviewers for its useful comments and suggestions. D. Taphorn kindly reviewed the English.

\section{References}

Ajiaco-Martínez RE, Ramírez-Gil H, Bolaños-Briceño JA. La pesquería en Bocas del Guayuriba, alto río Meta, Orinoquia colombiana. Villavicencio: Editorial Unillanos; 2015.

Bleeker P. Atlas ichthyologique des Indes Orientales Nèêrlandaises. Tome II. Siluroîdes, Chacoîdes et Hètèrobranchoîdes. Amsterdam: Muller; 1862.

Boeseman M. The "comb-toothed" Loricariinae of Surinam, with reflections on the phylogenetic tendencies within the family Loricariidae (Siluriformes, Loricariidae). Zool Verhand. 1971; 116:1-56.

Chang F, Castro E. Crossoloricaria bahuaja, a new loricariid fish from Madre de Dios, southeastern Peru. Ichthyol Explor Freshw. 1999; 10(1):81-88.

Covain R, Fisch-Muller S. The genera of the Neotropical armored catfish subfamily Loricariinae (Siluriformes: Loricariidae): a practical key and synopsis. Zootaxa. 2007; 1462(1):1-40.
Covain R, Fisch-Muller S, Oliveira C, Mol JH, Montoya-Burgos JI, Dray S. Molecular phylogeny of the highly diversified catfish subfamily Loricariinae (Siluriformes, Loricariidae) reveals incongruences with morphological classification. Mol Phylogenet Evol. 2016; 94:492-517. Available from: https:// doi.org/10.1016/j.ympev.2015.10.018

Delsman, HC. Résultats scientifiques des croisières du navireécole belge "Mercator", vol. III, No. 3. Pisces. Mem Mus R Hist Nat Belg. 1941; 2(21):47-82.

Fichberg I, Oyakawa OT, de Pinna M. The end of an almost 70year wait: a new species of Spatuloricaria (Siluriformes: Loricariidae) from the rio Xingu and rio Tapajós basins. Copeia. 2014; 2014(2):317-24.

Fricke R, Eschmeyer WN, Van der Laan R, editors. Eschmeyer's Catalog of Fishes: Genera, Species, References. San Francisco: California Academy of Science; 2019 [cited 2019 March 14] Available from: http://researcharchive.calacademy. org/research/ichthyology/catalog/fishcatmain.asp

Günther A. Descriptions of some species of fishes from the Peruvian Amazons. Proc Zool Soc London. 1869; 37(1):42329. Available from: https://doi.org/10.1111/j.1469-7998.1869. tb07347.x

International Union for Conservation of Nature (IUCN). Standards and Petitions Subcommittee. Guidelines for using the IUCN Red List categories and criteria. Version 13 [Internet]. 2017[accessed June 2019]. Available from: http://www. iucnredlist.org/documents/RedListGuidelines.pdf

Isbrücker IJH. Pseudohemiodon (Planiloricaria) cryptodon, a new species and subgenus from Peru (Pisces, Siluriformes, Loricariidae). Zool Beiträge. 1971; 21(3/4):274-83.

Isbrücker IJH. Redescription and figures of the South American mailed catfish Rineloricaria lanceolata (Günther, 1868) (Pisces, Siluriformes, Loricariidae). Beaufortia. 1973; 21(278):75-89.

Isbrücker IJH. Pseudohemiodon thorectes, a new species of mailed catfish from the rio Mamoré system, Bolivia (Pisces, Siluriformes, Loricariidae). Beaufortia. 1975; 23(300):85-92.

Isbrücker IJH. Description préliminaire de nouveaux taxa de la famille des Loricariidae, poissons-chats cuirassés néotropicaux, avec un catalogue critique de la sous-famille nominale (Pisces, Siluriformes). Rev Fr Aquariol. 1979; 5(4):86-117.

Isbrücker IJH. Classification and catalogue of the mailed Loricariidae (Pisces, Siluriformes). Verslagen em Technische Gegevens. 1980; 22(1):1-181.

Isbrücker IJH, Nijssen H. Rhadinoloricaria gen. nov. and Planiloricaria, two genera of South American mailed catfishes (Pisces, Siluriformes, Loricariidae). Beaufortia. 1974; 22(290):67-81.

Isbrücker IJH, Nijssen H. Two new species and a new genus of neotropical mailed catfishes of the subfamily Loricariinae Swainson, 1838 (Pisces, Siluriformes, Loricariidae). Beaufortia. 1978; 27(339):177-206.

Isbrücker IJH, Nijssen H. Crossoloricaria rhami n. sp., un nouveau poisson-chat cuirassé du Rio Huacamayo, Pérou (Pisces, Siluriformes, Loricariidae). Rev Fr Aquariol. 1983; 10:9-12. 
Isbrücker IJH, Nijssen H. Pyxiloricaria menezesi, a new genus and species of mailed catfish from rio Miranda and rio Cuiabá, Brazil (Pisces, Siluriformes, Loricariidae). Bijdr Dierkd. 1984; 54(2):163-68.

Isbrücker IJH, Nijssen $\mathrm{H}$. New records of the mailed catfish Planiloricaria cryptodon from the upper Amazon in Peru, Brazil and Bolivia, with a key to the genera of the Planiloricariina. Bijdr Dierkd. 1986a; 56(1):39-46.

Isbrücker IJH, Nijssen H. Apistoloricaria condei, nouveau genre et nouvelle espèce de poisson-chat cuirassé, tribu Loricariini Bonaparte, 1831, du bassin du rio Napo, haute Amazone, Equateur (Pisces, Siluriformes, Loricariidae). Rev Fr Aquariol. 1986b; 12(4):103-08.

Kner R. Die Panzerwelse des K.K. Hof-naturalien-Cabinetes zu Wien. I. Abtheilung: Loricarinae. Denkschr Mathem Naturwiss $\mathrm{Cl}$ Kaiserlichen Akad Wiss Wien. 1853; 6:1-34.

López-Rojas HA, Machado-Allison A. Algunos aspectos del desarrollo y crecimiento de Loricaria laticeps (Osteichthyes, Siluriformes, Loricariidae). Acta Biol Venez. 1975; 9(1):51-76.

Martín Salazar FJ, Isbrücker IJH, Nijssen H. Dentectus barbarmatus, a new genus and species of mailed catfish from the Orinoco basin of Venezuela (Pisces, Siluriformes, Loricariidae). Beaufortia. 1982; 32(8):125-37.

Morris PJ, Yager HM, Sabaj-Perez MH. ACSI imagebase: A digital archive of catfish images compiled by participants in the All Catfish Species Inventory [Image on the internet]. 2006 [cited 2018 Aug 15]. Available from: http://acsi.acnatsci.org/base

Nijssen H, Isbrücker IJH. Trois nouvelles espèces du genre Apistoloricaria de Colombie et du Pérou, avec illustration du dimorphisme sexuel secondaire des lèvres de $A$. condei (Pisces, Siluriformes, Loricariidae). Rev Fr Aquariol. 1988; 15(2):33-38.
Provenzano F. Estudio sobre las relaciones filogenéticas de las especies incluidas en la subfamilia Loricariinae (Siluriformes, Loricariidae). [PhD Thesis]. Caracas, Venezuela: Universidad Central de Venezuela; 2011.

Rapp Py-Daniel LH. Phylogeny of the Neotropical armored catfishes of the subfamily Loricariinae (Siluriformes: Loricariidae). [PhD Thesis]. Tucson: University of Arizona; 1997.

Regan CT. A monograph of the fishes of the family Loricariidae. Trans Zool Soc London. 1904; 17(3):191-351. Available from: http://dx.doi.org/10.1111/j.1096-3642.1904.tb00040.x

Sabaj MH. Standard symbolic codes for institutional resource collections in herpetology and ichthyology: an online reference. Washington, DC: American Society of Ichthyologists and Herpetologists; 2016. [cited 2018 Aug 15]. Available from: https://asih.org/sites/default/files/documents/symbolic_codes_ for_collections_v6.5_2016.pdf

Schaefer SA. The Neotropical cascudinhos: Systematics and biogeography of the Otocinclus catfishes (Siluriformes: Loricariidae). Proc Acad Nat Sci Philadelphia. 1997; 148:1-120.

Sciuiltz LP. The catfishes of Venezuela, with descriptions of thirtyeight new forms. Proc U S Natn Mus. 1944; 94(3172):173-338.

Soriano Señorans J. Nota preliminar sobre Loricaria (Loricaria) devicenzii n.sp. de la cuenca del río Uruguay. Rev Fac Human Cienc Montevideo. 1950; 4(5):265-66. 